\title{
FENOMENA SELEBGRAM ANAK: MEMAHAMI MOTIF ORANG TUA
}

\author{
Afdal Makkuraga Putra, Annisa Febrina \\ Universitas Mercu Buana, Jl. Meruya Selatan No. 1 Kembangan-Jakarta Barat 11650 \\ Telp: 021-584 0816 / email: afdal.makkuraga@mercubuana.ac.id
}

\begin{abstract}
Nowadays more and more child phenomenon shows up and the phenomenon of children's personal instagram accounts. This study aims to analyze the motives of parents to upload photos of children on Instagram. This research uses Alfred Schutz's phenomenology theory with the constructivist paradigm and phenomenology method. To collect data is done by in-depth interviews with 10 informants, and observations of the informants' instagram accounts. The results of the study and data analysis showed that there were a number of Motives because of uploading photos of children on Instagram that were driven by two things: the experience of photo albums in the past and the disruption and limitations of the technology possessed by parents. While the Motives for (in order to motives) found are related to 3 things. First, it relates to parents' efforts to make their children known to many people. Second, it relates to a demand to share the moment of child development with others, especially to distant families or friends who have not been met for a long time. Third, as an effort to realize the pride and gratitude of the parents for what they currently have. Based on the motives above, this study categorizes 3 Typics of Parents in uploading photos of children on Instagram, namely Existing Parents, Sharing Parents, and Memories of Parents. This research provides substance in the form of a new model about the type and motivation of parents to upload photos of children on Instagram.
\end{abstract}

Keywords: Instagram, phenomenology, new media, sharenting

\begin{abstract}
ABSTRAK
Saat ini semakin banyak muncul fenomena selebgram anak dan fenomena akun instagram pribadi anak. Penelitian ini bertujuan untuk menganalisis motif orang tua mengunggah foto anak di instagram. Penelitian ini menggunakan teori fenomenologi Alfred Schutz dengan paradigma konstruktivis dan metode fenomenologi. Untuk mengumpulkan data dilakukan dengan wawancara mendalam terhadap 10 informan, dan observasi terhadap akun instagram para informan. Hasil penelitian dan analisis data menujukkan terdapat beberapa Motif Karena (because motives) dalam mengunggah foto anak di instagram yang digerakkan oleh 2 hal yaitu pengalaman tentang album foto di masa lalu dan gangguan serta keterbatasan teknologi yang dimiliki oleh para orang tua. Sedangkan Motif Untuk (in order to motives) yang ditemukan terkait dengan 3 hal. Pertama, berkaitan dengan upaya orang tua untuk menjadikan anak mereka dikenal oleh banyak orang. Kedua, berkaitan dengan sebuah tuntutan untuk berbagi moment perkembangan anak kepada orang lain terutama kepada keluarga yang jauh ataupun teman-teman yang sudah tidak lama di temui. Ketiga, sebagai upaya untuk mewujudkan rasa bangga dan bersyukurnya para orang tua atas apa yang mereka miliki saat ini. Berdasarkan motif di atas, penelitian ini mengkategorikan 3 tipikasi Orang Tua dalam mengunggah foto anak di instagram yaitu Orang Tua Eksis, Orang Tua Sharing, dan Orang TuaMemories. Penelitian ini memberikan substansi berupa model baru tentang tipe dan motivasi orang tua mengunggah foto anak di Instagram.
\end{abstract}

Kata kunci: Instagram, fenomenologi, media baru, sharenting

\section{Pendahuluan}

Instagram, aplikasi media sosial yang diciptakan oleh Kevin Systorm dan Mike Krieger tahun 2012 ini bukan hanya menjadi aplikasi berbagi foto bagi penggunanya, tetapi sudah menjadi sarana memperoleh keuntungan. Hal tersebut terjadi tidak lepas dari perkembangan teknologi komunikasi dewasa ini berlangsung demikian pesat sehingga Coyle and H. Vaughn (2008) 
menyebut gejala ini sebagai suatu revolusi. Aplikasi berbagi foto dan video Instagram bisa disebut sebagai media sosial favorit berikutnya bagi milenial di Indonesia. Menurut hasil survey WeAreSocial.net dan Hootsuite pengguna Instagram sampai dengan Januari 2018 mencapai 800 juta, 55 juta terdapat di Indonesia atau terbanyak ketiga. Pengguna terbanyak pertama berada di Amerika Serikat yang mencapai 110 juta, lalu disusul Brazil dengan 57 juta pengguna aktif(katadata.co.id). Menurut Sri Widowati, Country Director Facebook Indonesia, seperti yang dikutip oleh Dailysocial. id (2 Agustus 2018) bahwa Indonesia tergolong pengguna aktif dalam membuat konten Instagram Story, dimana pengguna mengunggah konten dua kali lebih banyak dari jumlah konten rata-rata pengguna Instagram Story secara global. Pengguna aktif Instagram Story sendiri diungkap telah mencapai 250 juta pengguna.

Instagram memang sangat digandrungi oleh kaum milenial. Media soaial ini memiliki kelebihan dibanding dengan media sosial lainnya. Instagram memungkinkan penggunanya mengambil foto, menerapkan filter digital, dan membagikannya ke berbagai layanan jejaring sosial, termasuk milik Instagram sendiri. Instagram merupakan media sosial yang fitur-fiturnya memfokuskan aplikasi foto, video dan telah menyita banyak perhatian pengguna online.

Jika dahulu kita sering menyimpan foto kita di album foto yang tentunya harus di cetak terlebih dulu, maka kini kita bisa menyimpan foto secara online atau digital tanpa harus takut foto tersebut usang termakan waktu.
Menurut situs Instagram, aplikasi Instagram didirikan oleh Kevin Systrom dan Mike Krieger. Instagram dirilis pada Oktober 2010. Instagram merupakan aplikasi yang untuk berbagi foto atau gambar kepada teman-teman sesama pengguna instagram. Foto-foto di Instagram dapat dijadikan kenangan untuk bisa dilihat kedepannya, dapat mengekspresikan keadaan yang sedang terjadi dan telah terjadi. Pengguna media sosial Instagram menginginkan reaksi dari teman-teman atau kerabat mereka dan saling memberikan komentar dan like dari foto maupun video yang diunggah.

Mengunggah foto anak ke media sosial mungkin telah menjadi hal yang lazim. Faktanya tak sedikit bahaya yang bisa terjadi pasca orang tua mengunggah foto anak-anak mereka ke media sosial. Beberapa waktu yang lalu, publik tanah air dikejutkan dengan sindikat penjualan bayi murah di Instagram. Sekarang sindikat penjualan bayi sejenis juga muncul di Instagram, lewat akun@jualbayicantik. Akun ini menunggah foto bayi mirip Thalia Putri Onsu. Putri dari pasangan Ruben Onsu dan Sarwendah. Pelakunya mengaku mengambil foto anak Ruben Onsu dari akun Instagram milik artis tersebut.

Tentunya ini menjadi ketakutan tersendiri bagi para orang tua yang sering mengunggah foto anaknya di jejaring sosial seperti Instagram. Dengan berbagai akses informasi yang ada di Instagram tersebut baik melalui caption, geotagging, maupun koneksi ke jejaring sosial lainnya, tidak menutup kemungkinan bisa terjadinya tindak kriminal seperti penyalahgunaan 
foto anak, penculikan anak dan lain-lain. Walaupun begitu ada pula yang tetap mengunggah foto anaknya bahkan setelah begitu banyak kasus kriminal anak beredar. Selanjutnya terkait dengan kemunculan fenomena selebgram anak yang kini makin marak di Instagram. Di Indonesia sendiri sudah banyak selebgram anak bermunculan. Hal ini tentunya tidak terlepas dari peran orang tua sebagai orang yang mengunggah foto maupun video anaknya lalu kemudian membuatkan Instagram pribadi untuk anaknya.

Selebgram anak di Indonesia adakalanya anak-anak dari para public figure yang sudah menggeluti bidang entertainment seperti Rafatar, tiga tahun, anak pasangan pesohor Raffi Ahmad dan Nagita Slavina yang punya akun Instagram@(rafathar_club. Namun tak jarang pula datang darimasyarakat biasa seperti Ayasha Putri, lima tahun (@ayashaputri), anak pasangan Zheldy Riandy dan Adinda Maherwari yang kini telah memiliki 485 ribu pengikut (follower). Mereka membiarkan para publik untuk mengetahui kehidupan pribadi mereka salah satunya dengan cara mengekspos anak-anak mereka di Instagram. Di sisi lain ada banyak juga selebgram anak yang muncul bukan karena siapa orang tua mereka melainkan apa yang orang tua mereka lakukan di Instagram, yang tidak lain adalah karena foto-foto anak yang di unggah oleh para orang tua mereka.

Banyaknya fenomena yang terjadi terkait mengunggah foto anak di Instagram membuat peneliti mengajukan rumusan masalah yakni apa dan bagaimana motif para orang tua mengunggah foto anak di akun Instagram milik mereka? bagaimana mereka memaknai tindakan tersebut?

Penelitian ini menggunakan konsep fenomenologi. Secara terminologi, fenomenologi adalah ilmu yang berorientasi untuk mendapatkan penjelasan tentang realitas yang tampak. Fenomenologi menghubungkan antara pengetahuan ilmiah dengan pengalaman sehari-hari, dan dari kegiatan dimana pengalaman dan pengetahuan itu berasal. Konsep ini mendasarkan tindakan sosial pada pengalaman, makna dan kesadaran. Fenomenologi ini menurut Alfred Schutz, seorang sosiolog asal Austria tahun 1899 (Kuswarno. 2009:17). Inti pemikiran Schutz adalah bagaimana memahami tindakan sosial (yang berorientasi pada perilaku orang atau orang lain pada masa lalu, sekarang dan akan datang) melalui penafsiran. Fenomenologi mendasarkan tindakan sosial pada pengalaman, makna, dan kesadaran. Manusia dituntut untuk saling memahami satu sama lain, dan bertindak dalam kenyataan yang sama. Sehingga, ada penerimaan timbal balik, pemahaman atas dasar pengalaman bersama, dan tipikasi atas dunia bersama. Dengan kata lain, ia menyebut manusia sebagai “aktor”. (Kuswarno, 2009:18). Makna subjektif yang terbentuk dalam dunia sosial oleh aktor berupa sebuah "kesamaan" dan "kebersamaan" oleh karena itu disebut sebagai intersubjektif sebab tindakan sosial adalah tindakan yang berorientasi pada perilaku orang di masa lalu, sekarang dan masa datang (Kuswarno, 2009: 110). Menurut Schutz, dunia sosial merupakan sesuatu yang intersubjektif dan pengalaman 
yang penuh makna, dalam hal ini makna tindakan yang identik dengan motif yang mendasari tindakan tersebut.

Untuk menggambarkan seluruh tindakan seseorang, Schutz (1970) mengelompokkann motif dalam 2 kategori, yaitu: a) In-orderto-motive (Um-zu-Motiv), yaitu motif yang merujuk pada tindakan di masa yang akan datang. Tindakan yang dilakukan oleh seseorang pasti memiliki tujuan yang telah ditetapkan. b) Because motive (Weil Motiv), yaitu tindakan yang merujuk pada masa lalu. Tindakan yang dilakukan oleh seseorang pasti memiliki alasan dari masa lalu ketika ia melakukannya. Fenomenologi Schutz merupakan tawaran akan cara pandang baru terhadap fokus kajian penelitian dan penggalian terhadap makna yang terbangun dari realitas kehidupan sehari-hari yang terdapat di dalam penelitian secara khusus dan dalam kerangka luas pengembangan ilmu sosial.

Penelitian tentang penggunaan new media dalam berbagai kehidupan sosial sudah sering dilakukan diantaranya adalah Joshua Bowles (2016: 227-240) berjudul Instagram: A Visual view of the Southeastern Conference. Hasil penelitian menujukkan bahwa Instagram menjadi aplikasi berbagi foto berbasis mobile telah menjadi platform media sosial yang penting dengan basis pengguna yang tumbuh dari 200 juta pengguna aktif yang memasang 60 juta foto yang menghasilkan 1,6 miliar menyukai setiap hari (Instagram, 2014). Departemen atletik perguruan tinggi mulai menggunakan Instagram sebagai bagian dari keseluruhan strategi media sosial mereka. Hubungan media dan profesional pemasaran selalu mencari cara inovatif untuk menggunakan media sosial untuk terhubung dengan para pemangku kepentingan, dan Instagram telah menjadi cara unik untuk berbagi setiap program atletik dalam format visual. Sebuah analisis tematik dilakukan terhadap foto-foto yang dibagikan oleh anggota Konferensi Southeastern (SEC) mulai 1 September 2013 sampai 30 November 2013, di akun Instagram atletik resmi. Enam tema muncul dari analisis: (a) Aksi, (b) Behind the Scenes, (c) Fans, (d) Landmark, (e) Promotional, dan (f) Success. Penting bagi pengelola konten untuk menyadari bagaimana Instagram digunakan.

Hiram Ting dkk membuat penelitian berjuduk Beliefs aboutthe Use of Instagram: An Exploratory Study (2015) Penelitian ini dimuat pada International Journal of Business and Innovation. Vol. 2, Issue 2, 2015 halaman 15. Hasil penelitian menunjukkan bahwa keyakinan perilaku tentang Instagram terdiri dari lima faktor, dan mereka dicap sebagai kepuasan pribadi, fitur kegunaan, sosialisasi peran, informasi produk dan hiburan. keyakinan normatif, pada gilirannya, terdiri oleh enam faktor, dan mereka dicap sebagai saudara, kerabat, teman dekat / teman, teman pada umumnya, teman-teman Facebook, dan pengulas aplikasi.

Penelitian Cheung Ting Ting bejudul $A$ Study of Motives, Usage, Self-presentation and Number of Followers on Instagram (2014) Penelitian ini di ambil dalam Discovery - SS Student E-Journal Vol. 3, 2014, 1-35. Studi ini meneliti hubungan antara motif, penggunaan, 
presentasi diri dan jumlah pengikut di Instagram dengan menerapkan penggunaan dan teori kepuasan serta pendekatan manajemen kesan. Sebanyak 181 mahasiswa dari Universitas Kota Hong Kong direkrut untuk survei kuantitatif. Ditemukan bahwa motif yang positif dengan baik penggunaan dan presentasi diri, sementara jumlah pengikut juga menjelaskan untuk memiliki korelasi positif dengan menggunakan Instagram dan presentasi diri. Tidak ada hubungan kausal yang signifikan diperiksa antara motif dan jumlah pengikut.

Penelitian Eko Harry Susanto yang berjudul Media Sosial Sebagai Pendukung Jaringan Komunikasi Politik yang dimuat di Jurnal Aspikom volume 3 nomor 3 Juli 2017 , 379-397, menujukkan bahwa perkembangan teknologi komunikasi dan informasi semakin memudahkan interaksi antar individu maupun kelompok. Lalu lintas pesan dan pemberitaan tidak sepenuhnya dikuasai negara tetapi bebas mengalir pada khalayak. Media sosial yang memiliki kekuatan dalam penyebaran informasi menjadi pilihan untuk mempengaruhi, memotivasi, dan melakukan tindakan yang dikehendaki oleh penyebar pesan. Pada saat yang bersamaan, dominasi media massa arus utama semakin memudar. Pengguna media sosial tidak terikat oleh status sosial, ekonomi dan politik; media sosial dan media massa arus utama memiliki karakter berbeda dalam menyebarkan pesan kepada khalayak; dan media sosial merupakan pendukung jaringan komunikasi politik dalam demokrasi bernegara.

Penelitian Morissan berjudul Media Sosial dan Partisipasi Sosial di Kalangan
Generasi Muda yang dimuat di Jurnal Visi Komunikasi volume 13 No 1 Mei 2014, 50-68, menujukkan bawa pengguna media sosial dapat dikelompokkan ke dalam empat kategori. Keempat kategori ini menunjukkan peran-peran yang dipilih pengguna ketika mereka mengkonsumsi dan menikmati media sosial yaitu sebagai: penonton (watchers), pembagi informasi (sharers), komentator (commenters), dan produsen (producers)

Penelitian ini berbeda dengan penelitian terdahulu. Penelitian terdahulu tidak mengungkap tentang motif dan tipikasi orang tua mengunggah foto di Instagram, kemudian dari sisi metodologi penelitian terdahulu menggunakan metode fenomenologi. Penelitian ini menawarkan hal baru yakni hasil penelitian memetakan fenomena orang tua mengunggah foto anak di Instagram yang terjadi di kota besar.

\section{Metode Penelitian}

Untuk menjawab rumusan masalah peneliti mengunakan tipe penelitian kualitatif, metode penelitian fenemenologi, dengan teknik pengumpulan data melalui observasi dan wawancara kepada 10 orang tua yang gemar mengunggah foto anaknya di Instagram. Penelitian dilakukan di kota Jakarta, kota Tangerang, dan Ciputat, Tangerang Selatan pada akhir tahun 2017. Mereka yang diwawancara adalah: Aprilia Indah Sekar Lestari (ibu rumah tangga, tinggal di Ciputat), Riswin Hardiansyah (suami Aprilian Indah Sekar Lestari), Sakti (Karyawan TV Swasta di Jakarta), Andhika (Karyawan TV Swasta di Jakarta), Maya Luthfia (Ibu rumah tangga tinggal 
di Tangerang), Agustina Purwanti (Single Parent), Risa Harluni (ibu rumah tangga tinggal di Jakarta), Siti Sri Melati dan Pradita Octavian (pasangan suami istri) dan Yudhistira Arya Syahputra (Karyawan di Jakarta). Analisis data dilakukan dengan meramu data hasil wawancara dan hasil observasi kemudian membuat interpretasi dan kategorisasi. Metode keabsahan data triangulasi sumber melalui perbandingan data observasi pada akun Instagram narasumber dengan hasil wawancara.

\section{Hasil Penelitian dan Pembahasan}

Penelitian Anna Broach (2016, h 226235) menujukkan bahwa fenomena orang tua berbagi informasi tentang bayinya di media sosial sudah mendunia. Hal ini kemudian mendorong Collins Dictionary menambahkan kata sharenting untuk menjelaskan fenomena tersebut. Sharenting menurut Collins Dictionary adalah the practice of a parent to regularly use the social media to communi- cate a lot of detailed information about their child (atau tindakan orang tua yang secara regular menyebarkan informasi tentang anaknya di media sosial). Sejalan dengan hal tersebut mengunggah foto anak ke media sosial mungkin telah menjadi hal lazim yang sering dilakukan oleh sebagian orang tua. Orang tua senang dan bahagia ketika menunjukkan anaknya ke orang banyak dan menuai banyak pujian atas tumbuh-kembang sang anak.

Ditengah begitu gencarnya cybercrime --seperti data yang disampaikan oleh Wakapolri Komjen Syafruddin Indonesia adalah negera tertinggi kedua di dunia tingkat kejahatan cyber setelah Jepang sejak
2015 (CNNindonesia.com, 17 Juli 2018) para orang tua seakan pasrah dan hanya bisa berharap agar foto anak yang mereka unggah tidak disalahgunakan atau bahkan menjadi bahan cacian/bully masyarakat luas. Dengan begitu maraknya cybercrime, para orang tua mencoba belajar dari pengalaman para public figure yang pernah mengalami tindak kejahatan akibat mengunggah foto anak di media sosial khususnya Instagram. Namun, beberapa orang tua ada juga yang tidak terlalu mengambil pusing dengan masalah ini. Mereka mencoba untuk tetap berpikir positif dan menanggapi hal-hal ini dengan bijaksana tanpa perlu takut secara berlebihan.

"Kalo liat kasus kayak gitu sih tergantung kita nanggepin maksudnya, kalo terlalu banyak sentiment negatif sih harusnya ga perlu terlalu ditanggepin kali ya kalo kayak gitu-gitu. Kalo saya sendiri ngga ada ketakutan lah karna bukan public figure, terus followers saya belum banyak banget gitu, jadi ngga terlalu...seandainya followers saya juga banyak saya seneng sih. Biasa lah di sosial media ada yang negatif positif netral. Ada karakternya masing-masing kan user itu. Dan saya juga bukan orang yang cepet banget nge-reply apapun komen. Dibaca, disaring, ya kadang kalo temen dibales..." (Sekar)

Instagram dapat dibuat oleh siapa saja baik anak-anak, remaja, bahkan orang tua sekalipun. Mereka dapat mengunggah foto apapun misalnya foto makanan, foto tempat wisata, foto sedang berkumpul dengan kerabat atau teman-teman bahkan juga dapat mengunggah foto selfie hingga foto anak-anak. Foto anak biasanya banyak diunggah oleh para orang tua, baik orang tua baru atau yang baru memiliki anak maupun orang tua yang memang sudah sejak lama menggunakan Instagram. Foto anak-anak 
mungkin sudah tidak aneh bagi kita jika terpampang di berbagai media sosial. Diantara begitu banyaknya foto anak, pasti ada beberapa hal yang membedakan antara satu foto dengan foto lainnya. Seperti pada akun Instagram milik Maya Luthfia terdapat beberapa foto anaknya dengan berbagai gaya yang sangat sering menggunakan bandana, turban, jilbab dan aksesoris kepala sejenis. Hal ini dikarenakan memang anaknya tersebut merupakan anak perempuan.

"Seperti yang kita ketahui anak perempuan sering menjadi objek seni sang Ibu. Ibu mana yang tidak senang melihat anak perempuannya terlihat cantik dengan berbagai aksesoris." (Maya)

Ada juga foto anak dari Risa Harluni, seorang ibu rumah tangga yang berkat kegigihannya sering mengunggah foto anak ke Instagram dan mengikuti lomba-lomba di Instagram, ia membuat anaknya yang berusia enam bulan menjadi sering di-endorse oleh beberapa online shop. Diantaranya merk pampers, stroller, baju bayi dan lain-lain. Risa juga sering memasang foto anaknya dengan menggunakan aksesoris-aksesoris lainnya seperti bandana dan topi. Tidak hanya foto anak, Risa juga sering memposting giveaway, tips MPASI, publikasi lomba, publikasi jualan barang kebutuhan bayi dan masih banyak lagi dan itu semua ia posting bersamaan dengan foto-foto anaknya. Selain itu terdapat beberapa foto ketika sedang berlibur dan anak Risa mengenakan bikini untuk bayi dan kimono (baju tradisional jepang). Risa juga sering meng-upload foto setiap bulan di tanggal yang sama ketika anaknnya lahir untuk memperingati bertambahnya usia anak setiap bulan. Bahkan baru-baru ini Risa mulai mengunggah foto meme anaknya bersama anak temannya hanya untuk sekedar luculucuan saja.

Foto-foto anak pada akun Instagram yang diunggah oleh orang tua lainnya tidak memiliki ciri khusus. Mereka hanya memposting foto-foto anak sesuai momen, hal unik yang terjadi, dan lain-lain. Namun, ada beberapa orang tua yang ternyata pernah mem-posting foto anak setengah telanjang. Biasanya foto tersebut diambil saat momen anak sedang berenang atau sedang mandi. Seperti Sakti dan Maya yang memang pernah mem-posting foto anak setengah telanjang yaitu ketika mandi dan sehabis mandi.

Hal ini mereka lakukan semata-mata hanya untuk mengabadikan momen saja. Padahal sebenarnya, dalam mengunggah foto anak tentu ada etika yang harus diperhatikan terlebih lagi saat anak mengenakan busana minim atau setengah telanjang. Kita tidak pernah tahu siapa dan seperti apa orang yang melihat foto-foto kita di Instagram. Yudhis dan Riswin mengaku diantara begitu banyaknya foto anak yang pernah mereka unggah, ada satu foto yang paling berkesan dan sangat berharga yaitu foto ketika anak mereka lahir ke dunia. Foto ketika anak lahir memang yang paling sering di unggah pertama kali khususnya oleh para orang tua baru.

"Paling berkesan ya pertama kali lahir. Pertama kali lahir itu, dia masih kayak bundanya banget. Haha. Tapi makin lama makin kayak bokap nya, jadi udah makin item gitu. Hahaha. Pertama kali lahir soalnya putih banget. Jadi paling berkesan lah emang gede banget keliatannya gitu kan, matanya belo, terus apa, mukanya itu masih bersih banget lah lucu banget. Pertama kali lahir lah..." (Yudis dan Riswin). 
Menjadikan anak selebgram pernah terbesit didalam benak beberapa orang tua yang menginginkan anak-anak mereka bisa dikenal oleh banyak orang, lalu mendapatkan berbagai tawaran baik itu iklan maupun endorsement. Tak terkecuali orang tua yang menjadi informan dalam penelitian ini. Seperti Mela yang sempat berfikir untuk membuat vlog pribadi anaknya.

"Jadi gini, sempet ngobrol iseng sama Adit, bikin vlog lucu kali ya.. terus kayak punya akun pribadinya Alea gitu kan.. terus mikir lagi, ini anak masih kecil, emang sih kalo mikir panjang, ini anak bikin vlog kalo viewers-nya banyak, buat dia juga sebenarnya, maksudnya dari segi materinya.Ibu-ibu ya.. Hahaha. maksudnya suka iseng aja sih ca.kalo liat iklan susu atau pempers gitu kan...dan dia juga suka banget sama yang namanya iklan.. jadi, Alea mau ada disitu? Gitu gitu.. Cuma kalo dianya yg masih ngeliat bayi senyum-senyum ketawa-ketawa gitu.. Sempet kepikiran sih cuma mikir lagi.. masa anak gue harus nyari duit sih? Cuma aku pengennya sih iseng-iseng aja.. Waktu itu sih sempet ditawarin ternyata buat yang dua tahunan, tiga tahunan gitu..jadi Alea nya belum siap lahir batin ya ca. buat jadi bintang iklan. Ngga tau juga boleh apa engga ama bapaknya ya kan?" (Mela)

Mela tidak menyangkal ada keinginan ingin menjadikan anaknya selebgram dan dikenal oleh banyak orang. Sebagai Ibu, ia tentu bisa melihat potensi-potensi yang ada di dalam diri anaknya tapi disisi lain, ia juga berfikir bahwa anak-anak seharusnya menikmati juga masa-masa kecilnya tanpa harus tersentuh dengan popularitas dunia maya maupun dunia nyata. Ia juga takut terhadap dampak psikologis yang timbul jika anaknya tidak bisa menikmati masa kecilnya dan sibuk memikirkan materi walaupun tujuannya adalah untuk anak itu sendiri.

"Cuma akhirnya kita mikir, dia kan masih kecil belum ngerti apa-apa. Kedua, makin banyak orang yang tau, kemana-mana dia kayak ga punya privasi. Jadi lebih mikirin efek psikologisnya dia, mentalnya dia nanti. Terus akhirnya ya udahlah kita ga jadi... dulu sih sempet kepikiran, lucu kali yaa sering di posting, jadi di endorse.. tapi mikir lagi buat apa juga toh nge posting ini anak cuma sekedar buat ngehibur orang banyak." (Mela)

Maya dan Dhika mempunyai pendapat yang hampir sama. Mereka tidak pernah kepikiran untuk menjadikan anaknya selebgram tetapi mereka juga tidak akan menolak jika memang ada tawaran endorse ataupun iklan untuk anak mereka. Bagi mereka, selama itu positif dan masih dalam batas yang wajar, tidak akan ada masalah. Lagi pula mereka pun tidak memaksakan kehendak, namun tidak juga menolak bila ada rezeki.

Diantara para orang tua dalam penelitian ini, terdapat beberapa orang tua yang memang sengaja membuatkan Instagram untuk anaknya. Seperti Risa Harluni yang dengan sengaja membuat akun Instagram untuk kedua buah hatinya. Untuk Instagram anak pertama bernama Keanu, ia mengakui hanya iseng-iseng saja karena lebih kepada rasa excited mempunyai anak pertama. Namun, untuk anaknya yang kedua yang bernama Kimora, ia mengakui membuatkan Instagram pribadi untuk anaknya karena memang tuntutan dari online shop yang meng-endorse anaknya.

"Keanu punya akun Instagram tapi cuma aku iseng-iseng doang. Tapi kalo Kimora, akun Instagramnya disuruh bikin sama olshop.. Sama orang-orang yang mau endorse.. Karena kan masih jadi satu nih.. Jadinya mereka maunya akun Instagramnya sendiri gitu. Jadi lagi aku prepare jadi lebih rapi... Cuman belom aku publish karena masih nyusun foto." (Risa)

Maya Luthfia pun juga sempat membuatkan anaknya Instagram pribadi dengan 
nama akun@shakilakhumairahsb. Pada awalnya, Maya membuatkan akun Instagram pribadi anaknya agar tidak mengganggu akun pribadinya. Namun, Maya mengakui bahwa akun tersebut sekarang mulai tidak terlalu aktif dan bahkan ia pun sudah lupa dengan password akunnya. Peneliti pun mencoba mengecek akun tersebut dan foto terakhir memang di-upload pada Desember 2016. Berbeda dengan Dhika yang tidak membuatkan akun Instagram pribadi untuk anaknya walaupun pada awalnya ia sempat berniat membuatkannya

"Tadinya niat.. Cuman kayaknya repot kalo pake.. Ngurusin dua akun. Ada sih temen yang punya akun anaknya.. Cuman kayaknya repot juga.. Apa nanti.. Nanti di Instagram pribadi saya, nanti ngga ada foto anaknya.. Ya "kan.." (Dhika)

Lain halnya dengan Sakti, Mela, Adit, April dan Tina yang mengaku bahwa anak mereka sama sekali tidak memiliki akun Instagram pribadi. Tina merasa lebih baik jika anak-anaknya sendiri saja yang membuat akun Instagram mereka jika sudah cukup umur untuk membuat akun. Sependapat dengan Tina, April juga merasa tidak perlu membuatkan akun Instagram untuk anaknnya karena mereka pun belum bisa mengatur sendiri akunnya.

"Ya buat apa.. Kan yang megang ibu nya juga. Dan yang di-post pasti juga kan foto nya ituitu juga. Lagian anak kecil kan belom bisa pake Instagram" (April,)

Sakti mempunyai pemikiran bahwa anakanak sebaiknya tidak diperkenalkan dahulu dengan sosial media terutama Instagram. Baginya, Instagram belum memberikan manfaat yang berarti untuk anak-anaknya bahkan ia juga takut jika membuatkan anaknya akun Instagram, justru akan mempengaruhi tingkah laku sang anak. Memang sebagian besar orang tua yang menjadi informan dalam penelitian ini tidak membuatkan Instagram pribadi untuk anak-anaknya dikarenakan memang mereka merasa belum memerlukannya. Di sisi lain, peneliti merasa hal ini berkaitan dengan motif tujuan mereka mengunggah foto anak di Instagram.

"Nggak. Emang sengaja. Jadi memang sengaja ga diperkenalkan dengan Instagram sih karena menurut saya belum ada manfaatnya untuk mereka. Gitu.. Takutnya mereka ntar malah keranjingan Instagram, repot juga masih kecil" (Sakti,)

Dalam pandangan fenomenologi Schutz, dunia sosial merupakan sesuatu yang intersubjektif dan pengalaman yang penuh makna. Dalam hal ini makna tindakan identik dengan motif yang mendasari suatu tindakan. Schutz (1970) menggolongkan motif kedalam dua kategori yaitu motif karena (because motives) dan motif untuk (in order to motives). Motif karena yaitu tindakan yang merujuk pada masa lalu. Dimana, tindakan yang dilakukan oleh seseorang pasti memiliki alasan dari masa lalu ketika ia melakukannya. Sedangkan motif untuk yaitu motif yang merujuk pada tindakan di masa yang akan datang. Dimana, tindakan yang dilakukan oleh seseorang pasti memiliki tujuan yang telah ditetapkan.

Setelah mengamati dan melakukan wawancara yang mendalam dengan para informan di atas, peneliti menemukan bahwa para orang tua memiliki motif yang berbeda-beda dalam mengunggah foto anak di Instagram. Motif yang ditemukan akan dibagi menjadi dua bagian berdasarkan motif tindakan menurut Alfred Schutz. 


\section{Motif Karena (Because Motives)}

Motif Karena berkaitan dengan tindakan di masa lalu. Dalam penelitian ini, motif karena yang ditemukan dari para informan adalah terkait dengan pengalaman tentang album foto di masa lalu. Jauh sebelum munculnya berbagai teknologi seperti sekarang ini, kita masih menggunakan album foto untuk menyimpan berbagai foto sebagai kenangan yang dapat kita lihat kapan saja. Tentunya album foto pun terbatas dan bersifat tidak tahan lama karena sebuah foto yang dicetak akan terlihat usang saat termakan umur. Kualitas cetakan foto pada jamannya tentu berbeda dengan kualitas cetakan foto pada masa sekarang.

Selain itu, ternyata tidak semua orang pernah melihat foto kenangan masa lalu yang dicetak dan dimasukan ke album foto. Seperti Dhika yang menceritakan kepada peneliti tentang keinginannya melihat foto-foto masa kecilnya dahulu namun justru tidak bisa ia dapatkan karena album foto tersebut hilang entah kemana. Dhika mengaku bahwa memang dengan hadirnya teknologi new media seperti Instagram sangat membantu dalam mengumpulkan berbagai foto termasuk foto anak-anaknya. Ia juga tidak ingin anak-anaknya merasakan hal yang sama dengannya ketika dewasa nanti yaitu tidak bisa melihat foto-foto masa kecil mereka. Dengan mengunggah foto anak ke Instagram, Dhika bisa melihatnya kapan saja dan dimana saja, apalagi dengan sengaja ia menggunakan hastag \#RatuAndhinaLateesha dan \#Alaric ArkaPutraPrasasti untuk memudahkan dia dan bahkan orang-orang untuk menemukan foto-foto anaknya sejak awal ia mengunggah.
Motif karena lainnya berkaitan dengan gangguan dan keterbatasan teknologi yang dimiliki oleh para orang tua. Pengalaman mereka dengan keterbatasan dari memory card handphone bahkan ketika handphone mereka hilang, membuat para orang tua mencari solusi. Momen yang diabadikan lewat foto tentunya tidak ada yang dapat menggantikannya apalagi jika yang dicapture merupakan momen dari sang buah hati. Sangat disayangkan jika kita tidak bisa mengabadikan momen hanya karena memory card handphone yang kapasitasnya terbatas ataupun rusak. Tidak hanya itu saja, tentu akan sangat sedih juga ketika begitu banyak foto anak yang tersimpan di handphone namun ketika handphone tersebut hilang, foto pun akan ikut hilang begitu saja.

Bagi beberapa para orang tua dalam penelitian ini seperti Sakti dan Riswin mengunggah foto anak di Instagram didasari oleh pengalaman yang lalu yang mana memaksa mereka untuk mencari cara agar tetap bisa melihat foto anak kapan saja dan dimana saja tanpa adanya gangguan ataupun keterbatasan media.

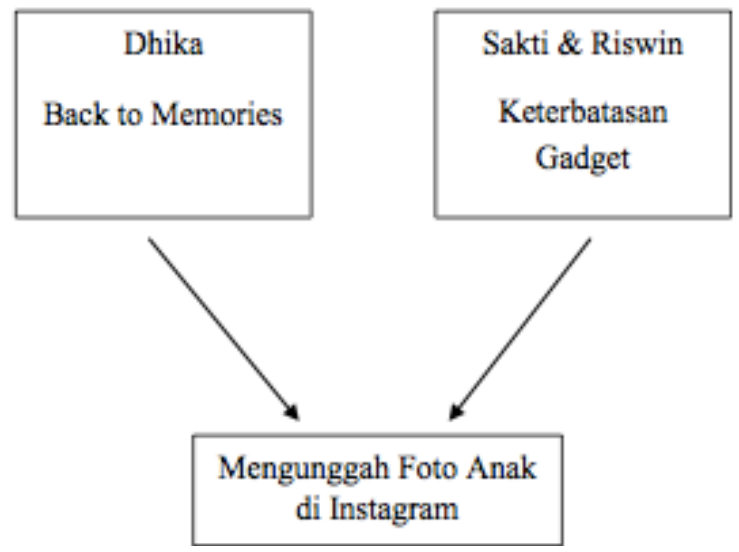

Gambar 1. motif "because of" Orang Tua Mengunggah Foto Anak di Instagram Sumber gambar: diolah dari hasil penelitian 


\section{Motif Untuk (In Order To Motives)}

Motif Untuk berkaitan dengan tindakan di masa yang akan datang. Dalam penelitian ini, motif untuk yang ditemukan dari para orang tua sangatlah beragam. Mengunggah foto anak bagi beberapa orang tua sudah menjadi kegiatan rutin setiap hari. Ada pula yang memanfaatkan hal yang rutin tersebut menjadi kesempatan untuk dapat dikenal oleh banyak orang. Seperti Maya yang sangat aktif mengunggah foto dari berbagai kegiatan anaknya. Sama halnya dengan Maya yang juga mulai sering mengikutsertakan anaknya ke berbagai lomba foto di Instagram, Risa juga awalnya hanya sekadar mengikutsertakan anaknya ke berbagai lomba foto, justru membawanya menjadi orang tua yang cukup sibuk belakangan ini karena mulai banyak online shop yang ingin menggunakan anaknya sebagai model endorse. Selain itu, berkat pergaulannya dengan para ibuibu yang anaknya menjadi selebgram, Risa pun terpengaruh untuk menjadikan anaknya selebgram juga. Motif lainnya bisa ditemukan saat melihat halaman Instagram milik Risa yang mana begitu banyak foto- foto tentang sharing pengalaman seputar ibu menyusui dan informasi kebutuhankebutuhan anak. Hal ini diakui Risa sebagai salah satu tujuan mengapa ia mengunggah foto anak di Instagram.

Motif Untuk lainnya di dapat dari para orang tua yang memang mengunggah foto anak sebagai sebuah keharusan untuk berbagi momen perkembangan anak kepada orang lain terutama kepada keluarga yang jauh ataupun teman-teman yang sudah tidak lama di temui. Seperti April dan Yudhis yang memang mengunggah foto di Instagram hanya untuk berbagi moment keceriaan dan perkembangan anak kepada keluarga mereka yang berada di Medan. Yang tadinya tidak begitu banyak keluarga yang tahu tentang anak mereka, justru menjadi tahu berkat foto yang mereka unggah. Tina pun demikian, ia ingin teman-teman yang sudah lama tidak ia jumpai, dapat mengetahui kabar dan keadaannya bersama anak-anaknya lewat foto yang ia unggah di Instagram.

Ada pula motif kebanggaan yang dirasakan oleh Mela dan Adit. Mela yang awalnya tidak menyangka sekarang sudah menjadi ibu mengakui bahwa mengunggah

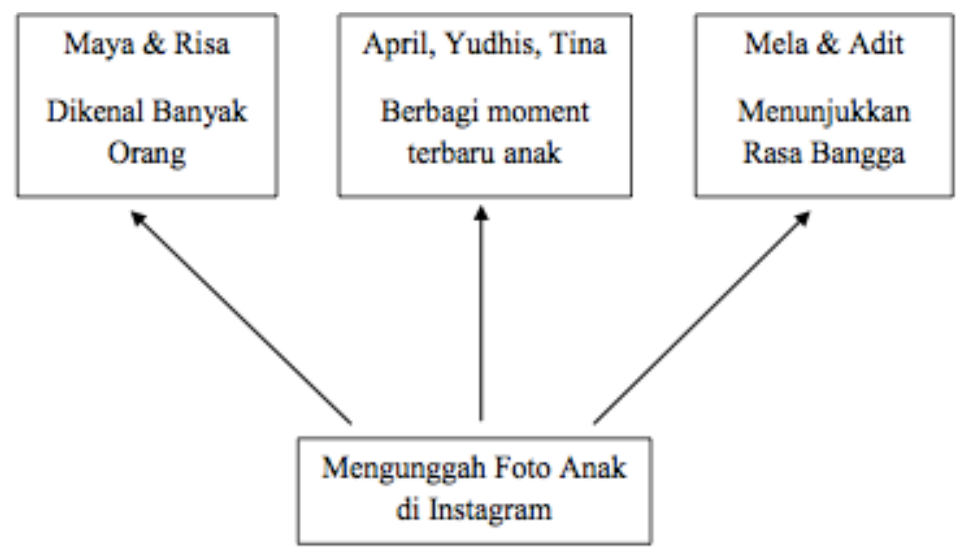

Gambar 2. Motif Untuk (in order to motives) Orang Tua Mengunggah Foto Anak di Instagram Sumber gambar: diolah dari hasil penelitian 
foto anak sebagai wujud rasa bangga dan bersyukur atas apa yang ia miliki saat ini serta timbulnya rasa ingin menunjukkan ke orang-orang tentang seberapa bangganya ia memiliki seorang anak.

Schutz juga membuat sebuah model tindakan manusia yang dibuat melalui proses yang dia beri nama "tipikasi". Tipikasi berlangsung sepanjang hidup manusia. Jenisnya bergantung pada orang yang membuatkannya sehingga kita dapat mengenal tipe-tipe aktor, tindakan, kepribadian seseorang dan sebagainya. Jenis tipikasi dibuat berdasarkan kesamaan tujuan, namun dalam struktur yang relevan dengan objek penelitian (Kuswarno, 2009: 38-39).

Peneliti membuat tipikasi identitas para orang tua yang mengunggah foto anaknya di Instagram ke dalam 3 kelompok berdasarkan kesamaan motif, yaitu Orang Tua Eksis, Orang Tua Sharing dan Orang Tua Memories.

\section{a. Orang Tua Eksis}

Orang tua dalam tipikasi pertama ini adalah orang tua yang sangat aktif dalam beraktivitas di Instagram, baik itu mengunggah foto anak, mengikutsertakan anak ke berbagai lomba, maupun menggunakan fitur-fitur di Instagram seperti Insta Stories, Insta Live, Hashtag, dan lainlain. Selain itu orang tua Eksis ini juga sangat gencar menampilkan segala aktivitas anaknya di Instagram. Mereka sangat senang jika apa yang mereka tampilkan mendapat respon dari orang banyak walaupun dari orang-orang yang tidak dikenal.

Risa mengunggah foto anak lebih dari tujuh kali dalam seminggu. Ia juga menampilkan foto yang berbeda-beda dan disusun cukup rapi agar enak dilihat. Kegemaran Risa mengikutsertakan anaknya lomba foto di Instagram berbuah kesempatan untuk di-endorse berbagai produk dari online shop. Ia dituntut untuk mem-posting foto setiap hari dan juga harus membuatkan akun Instagram pribadi untuk anaknya sebagai bentuk feedback dari online shop yang meng-endorse anaknya.

Maya juga masuk ke dalam tipikasi orang tua eksis. Ia sangat aktif dalam mengunggah foto anak disertai caption yang panjang dan mendalam. Terhitung ia dapat mengunggah foto anak lebih dari enam kali dalam seminggu. Ia juga sangat sering menggunakan InstaStories di berbagai kesempatan. Maya juga cukup sering mengikutsertakan anaknya ke dalam lomba-lomba foto.

Orang tua dengan tipikasi ini selalu menunjukkan foto-foto yang bagus dengan caption yang cukup panjang dan disertai dengan hashtag-hashtag sesuai caption. Caption foto pun kadang berisikan ungkapanungkapan dan cerita- cerita panjang di balik foto tersebut. Intensitas yang tinggi dalam menggunakan fitur seperti Instastories dan InstaLive juga menjadi karakteristik orang tua Eksis. Selain itu, orang tua dalam tipikasi ini juga sering melakukan kegiatan sharing parenting seputar dunia anak. Ramah dan terlihat baik di mata orang lain juga menjadi karakteristik lainnya dalam orang tua eksis ini. Bagi mereka, respon orang lain sangat berharga. Ketika mereka baik dan ramah dengan orang lain, pasti orang lain akan juga merespon dengan baik, sebagai berikut (gambar 5): 


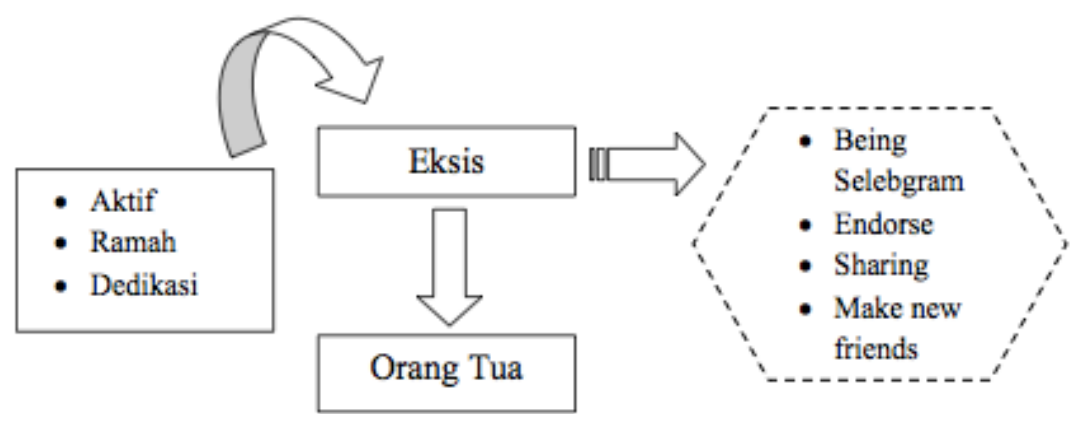

Gambar 3. Diagram Jenis Orang Tua Eksis

Sumber gambar: diolah dari hasil penelitian

\section{b. Orang Tua Sharing}

Sharing atau dalam bahasa Indonesia adalah berbagi. Orang tua dalam tipikasi ini menganggap bahwa mengunggah foto anak adalah sebuah kebanggaan yang perlu dibagi ke orang lain. Tidak hanya itu, bagi mereka, mengunggah foto anak merupakan suatu keharusan sebagai bentuk menyebarluaskan kegiatan anak demi memenuhi permintaan orang lain khususnya keluarga dan temanteman. April, Adit, Mela dan Yudhis masuk ke dalam tipikasi orang tua sharing. Seperti April yang memang mengunggah foto anak demi menyenangkan keluarganya di Medan agar dapat melihat seluruh kegiatan dan perkembangan sang anak. Berbagi momen dan kebahagiaan serta menunjukkan rasa bangga terhadap anaknya kepada orang lain menjadi karakteristik dalam tipikasi ini.

Mela yang mengaku kepada peneliti bahwa cara ia menunjukkan rasa bangga dan bahagianya ia menjadi seorang ibu adalah melalu mengunggah foto-foto anaknya yang berumur satu tahun tersebut. Tidak berbeda jauh dengan suaminya, Adit yang juga masuk ke dalam tipikasi orang tua sharing. Adit sebagai keturunan darah Manado, sangat bangga memiliki anak perempuan, ia mengaku dalam silsilah keluarganya, jika memiliki anak perempuan, menjadi sesuatu yang berharga dalam keluarga tersebut. Itulah mengapa ia mengunggah foto anak.

Yudhis pun demikian, sebagai Ayah baru, ia hanya ingin menunjukkan ke orang-orang terutama keluarga nya bahwa sekarang ia sudah mempunyai anak. Apalagi, semenjak ia mengunggah foto anak, mulai banyak keluarga atau kerabat yang awalnya tidak pernah ia tahu, justru sekarang menjadi lebih sering berkomunikasi bertegur sapa di Instagram.

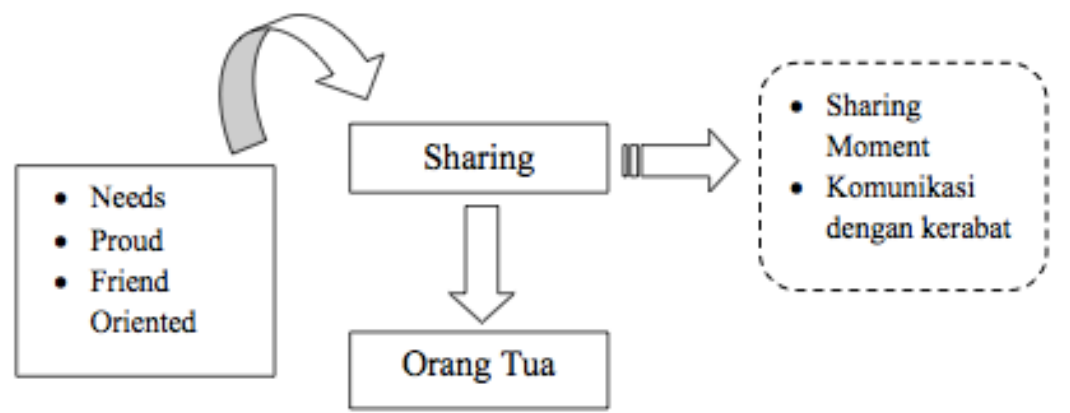

Gambar 4. Diagram Tipe Orang Tua Sharing Sumber gambar: diolah dari hasil penelitian 


\section{c. Tipe Orang Tua Memories}

Sebuah memori atau kenangan menjadi hal yang paling berharga bagi para orang tua yang masuk ke dalam tipikasi ini. Orang tua memories sangat family oriented, artinya, bagi mereka keluarga adalah segalanya. Memori dengan keluarga terutama dengan anakanak mereka adalah memori yang tidak bisa didapatkan kembali. Dhika, Sakti, Riswin dan Tina termasuk kedalam tipikasi orang tua memories. Tiga di antara mereka memiliki motif masa lalu yang menyebabkan mereka mengunggah foto anak. Dhika yang mengaku kepada peneliti bahwa ia ingin anak-anak mereka tidak mendapatkan pengalaman yang sama dengan Ayahnya yang tidak bisa melihat foto kenangan di masa kecilnya dulu. Itulah sebabnya Dhika mengunggah foto sebagai memori jangka panjang yang ketika anakanaknya dewasa, mereka dapat melihat foto kecil mereka dari awal di unggah.

Perubahan teknologi telah mengubah cara pikir kita untuk bisa mengikuti arus. Kehadiran teknologi new media seperti Internet yang didalamnya terdapat aplikasi-aplikasi pintar dan berguna seperti Instagram, mengubah manusia yang awalnya menggunakan album foto untuk menyimpan foto, sekarang justru menggunakan Instagram sebagai album digital versi mereka. Memang di antar begitu banyak media sosial, Instagram-lah yang paling popular untuk menyimpan dan berbagai foto dan video. Tidak seperti sosial media lainnya yang terlalu banyak memiliki fitur.

Dengan keterbatasan teknologi seperti handphone ataupun memory card untuk menyimpan berbagai file, Instagram hadir seakan memberikan solusi. Hanya dengan terkoneksi internet, siapa pun, kapan pun dan dimana pun akan dapat masuk ke dalam akun Instagram-nya. Hal ini lah yang di alami Sakti dan Riswin sehingga mereka masuk kedalam tipikasi orang tua memories. Mereka menganggap tidak ada yang dapat membatasi seseorang untuk mengunggah memori berharga mereka selama adanya Instagram.

Sebagai single parent yang tidak bekerja, Tina menjadi sangat sering menghabiskan waktu bersama anak-anaknya. Kedekatannya dengan mereka membuat peneliti memasukkannya ke dalam tipikasi orang tua memories. Seperti yang diakui Tina, ia masih bisa bertahan seperti sekarang ini hanya karena demi anak-anaknya. Mengunggah foto anak seperti membuat sebuah memori yang berharga untuknya. Tina ingin menunjukkan betapa bahagianya ia sekarang dengan anakanaknya. Ia juga mengaku bahwa semua foto anak yang diunggah memiliki cerita tersendiri. Jadi, karakteristik orang tua memories ini

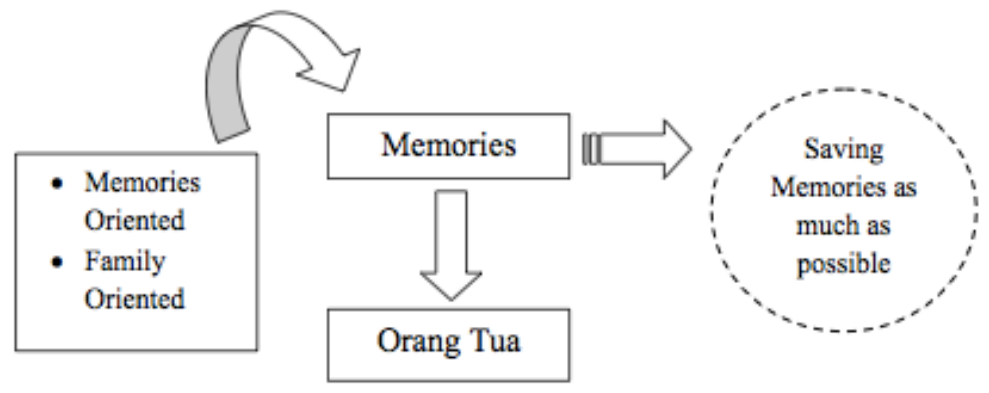

Gambar 5. Diagram Tipe Orang Tua Memories

Sumber gambar: diolah dari hasil penelitian 
memang lebih menekankan kepada family oriented dan memories oriented. Mereka tidak mempunyai maksud ataupun tujuan tertentu dalam mengunggah foto anak tetapi memang murni hanya untuk menyimpan memori bersama anak sebanyak mungkin agar nanti dapat mereka lihat ketika mereka dewasa.

Implikasi teoritis penelitian ini, meskipun konsep-konsep fenomenologi yang dibangun Schutz ini tergolong lama dalam khasanah ilmu sosial, namun konsep ini masih sangat relevan digunakan untuk mengkaji fenomena baru dimasyakat termasuk maraknya penggunaan media sosial sebagai sarana komunikasi.

\section{Simpulan}

Terdapat beberapa motif yang ditemukan dari para orang tua sesuai dengan pernyataan Schutz yaitu berdasarkan motif karena (because motives) dan motif untuk (in order to motives) antara lain: Motif Karena atau motif masa lalu yang digerakkan oleh dua hal yaitu pengalaman tentang album foto di masa lalu dan gangguan serta keterbatasan teknologi yang dimiliki oleh para orang tua. Pengalaman mereka dengan keterbatasan dari memory card handphone bahkan ketika handphone mereka hilang, membuat para orang tua mencari solusi untuk tetap bisa melihat dan menyimpan foto anak mereka.

Sedangkan motif Untuk atau motif masa depan terkait dengan tiga hal. Pertama berkaitan dengan upaya orang tua untuk menjadikan anak mereka dikenal oleh banyak orang dengan mengikuti berbagai lomba dan mulai menjajaki dunia selebgram. Kedua, berkaitan dengan sebuah tuntutan untuk berbagi moment perkembangan anak kepada orang lain terutama kepada keluarga yang jauh ataupun teman-teman yang sudah tidak lama ditemui. Ketiga, sebagai upaya untuk mewujudkan rasa bangga dan bersyukurnya para orang tua atas apa yang mereka miliki saat ini dengan timbulnya rasa ingin menunjukkan ke orang-orang tentang seberapa bangganya ia memiliki seorang anak.

Substansi penelitian ini menemukan model baru motif dan tipikasi orang tua mengunggah foto anak di Instagram. Karena penelitian ini adalah kualitatif maka hasil penelitian tidak bisa digeneralisasi dan hanya berlaku pada subyek penelitian ini, untuk itu perlu diteruskan dengan menggunakan pendekatan fungsionalisme Parson atau reprentasi makna menurut Saussure atau Sturukturasi Gidden atau pendekatan posivistik untuk mengetahui perilaku pengguna media sosial secara obyektif sehingga topik-topik tentang media baru makin kaya.

\section{Daftar Pustaka}

Bowles, Josua. (2016). Instagram: A Visual view of the Southeastern Conference. Journal of Contemporary Athletics Volume 10, No. 4, 2016.

Broach, Anna, (2016), When the Child is Born into the Internet: Sharenting as a Growing Trend among Parents on Facebook. Journal on The New Education Review, DOI: 10.15804/tner.2016.43.1.19

C. L. Coyle and H. Vaughn, "Social networking: Communication revolution or evolution?," in Bell Labs Technical Journal, vol. 13, no. 2, pp. 13-17, Summer 2008. doi: 10.1002/bltj.20298

Hidayat, Dedy N. (2003). Paradigma dan Metodologi Penelitian Sosial Empirik. Jakarta. 
Kuswarno, Engkus. (2009). Metodologi Penelitian Komunikasi Fenomenologi. Bandung: Widya Padjajaran

Lister, M. (2009). New Media: a critical introduction second edition. New York: Routledge

Morissan, Media Sosial dan Partisipasi Sosial di Kalangan Generasi Muda, Jurnal Visi Komunikasi volume 13 No 1 Mei 2014

Schutz, Alfred, (1971) On Phenomenology and Social Relation, University Chicago Press
Susanto, Eko Harry, Media Sosial Sebagai Pendukung Jaringan Komunikasi Politik, Jurnal Aspikom volume 3 nomor 3 Juli 2017

Ting Ting, Cheung, A Study of Motives, Usage, Self-presentation and Number of Followers on Instagram, Discovery-SS Student E-Journal Vol. 3, 2014.

Ting, Hiram, Beliefs about the Use of Instagram: An Exploratory Study, International Journal of Business and Innovation. Vol. 2, Issue 2, 2015 